\title{
Blood Group Lipoids from Human Gastric Mucosa and Gastric Cancer.*
}

\author{
By \\ Syozi Siozima. \\ (塩島 正二)
}

(From the Medico-chemical Institute, (Director: Prof. H. Masamune) and the Medical Clinic of Prof. T. Kurokawa, Tohoku University, Sendai.)

(Received for publication, April 29, 1951)

This investigation was undertaken to compare, regarding the composition, not only $\mathrm{A}, \mathrm{B}$ and $\mathrm{O}$ group lipoid of the gastric mucosa with one another but also one of the corresponding lipoids of gastric cancer with them. The tissue lipids extractible with hot alcohol were fractioned in a similar manner as already reported, ${ }^{1}$ ' but the final stage by means of hot alcohol was not processed due to lack of material excepting when those from the mucosa of stomachs of Group A persons were dealt with. In this case, however, there was given no subdivision allusive to a pure state of the lipoid. Despite of the probable crudeness, the preparations (The subdivisions of the Group A lipoid by the final stage operation are excluded) of the different group lipoids gave nearly concordant figures: $\mathbf{N}$ $3.6-3.9 \%$, P 2.6-2.8\%, total carbohydrate as glucose 9.4-11.9\%, ash $7.8-12.4 \%(3.9-4.3 \% \mathrm{~N}, 2.8-3.1 \% \mathrm{P}$ and $10.3-13.1 \%$ total carbohydrate on an ash-free basis). The equivalent ratios of $\mathrm{N}$ to $\mathrm{P}, 2.9-3.1: 1$. On these analyses, the writer inclines to believe that the different blood group lipoids of gastric mucosa and gastric cancer resemble all one another or rather identical in so far as the composition concerns.

Of the lipoids from the normal mucosa; the Group A substance was anti-iso-hemoagglutinative at a dilution of $1: 2.56 \times 10^{4}-5.12 \times 10^{4}$ and the Group B substance at a dilution of $1: 2.56 \times 10^{4}$, and the Group $O$ substance inhibited the agglutination of $\mathrm{O}$ erythrocytes by an anti-O immune serum treated in advance with Be erythrocytes at a dilution of $1: 1.28 \times$ $10^{4}$. The Group A substance from gastric cancer was specifically active at a dilution of $1: 6.4 \times 10^{3}$. That the group lipoid from gastric cancer is distinctly less active than the corresponding substance of the normal mucosa reminds the writer of the weak activity of the group lipoid which

\footnotetext{
* 8th report of Masamune and co-workers' "Chemistry and Biology of Lipids."
} 
was separated by Aikawa ${ }^{2}$ from a metastasis of gastric cancer in a person belonging to Group B and had like contents of $\mathrm{N}(3.6 \%)$ and $\mathrm{P}(2.6 \%)$ (ash, $8.10 \%$ ) as above. (The author applied indole, orcinol and diphenylamine methods immediately to his preparations for sugar determination, but the values obtained are much larger than the actual as $\mathbf{M a t u d a}^{8}$ mentioned and, in addition, what they signify is obscure.)

Judging from the analyses of the group lipoids (concentrates) of erythrocytes (Hamasato $\left.{ }^{4}\right)$ and of liver (Matuda $\left.{ }^{8}\right)$ as well as the finding above, the group lipoids involve $\mathrm{N}$ and $\mathrm{P}$ in a ratio characteristic to their source. Hence the $\mathrm{N}: \mathrm{P}$ ratio of the group lipoid in gastric cancer furnishes a proof that gastric cancer has a group lipoid which is peculiar to its site and differ from the one in the normal mucosa only in the grade of differentiation. And, moreover, it is most plausibly assumed that Aikawa's lipoid from the metastasis and the corresponding lipoid in the original growth are identical just like the group carbohydrates of those primary and secondary tumors (Cf. Oh-Utit) and Matuda ${ }^{6}$ ).

What kind of change in structure or molecular form or in some other respect accompanies the biological differentiation must be a very important problem awaiting solution.

\section{EXPERIMENTAL.}

1) The Group Lipoid from the Mucosa of Stomachs of Persons Belonging to Group A.

The mucosa torn from muscularis externa was freed mechanically from mucus and minced. $1254 \mathrm{~g}$. of the fresh material thus obtained from 19 stomachs were dehydrated by keeping under 4 volumes of alcohol for many days. $224 \mathrm{~g}$. was the material dried. It was boiled twice with abs. alcohol ( 5 and 3.5 volumes were used). The extracts were $1800 \mathrm{cc}$. altogether. After standing overnight the sticky deposits were filtered off and set aside-Div. II (1.5 g.). The filtrate (light brown and transparent) was distilled in vacuo and the semifluid residue-Div. I-was covered under $100 \mathrm{cc}$. of acetone for hours. The acetone-insoluble part was separated and after washing with changes of acetone until no colored matter came out, placed in a desiccator. $4.5 \mathrm{~g}$. of a brownish clayey substance (hygroscopic) were yielded. From another batch of tissue material $(481 \mathrm{~g}$. in fresh state, $68 \mathrm{~g}$. when dehydrated) was given $0.8 \mathrm{~g}$. of the division corresponding to Div. II above-Div. II'-and $1.2 \mathrm{~g}$. of the acetone-insoluble part of the division corresponding to Div. I above (Div. I').

The balances of the acetone-insoluble parts of Divs. I and I', after serological and other assays, were united (total weight $5.5 \mathrm{~g}$., anti-isohemoagglutinative at a dilution of $1: 3200$ ), exhaustively treated with cold abs. alcohol (Five $30 \mathrm{cc}$. portions of abs. alcohol were used; the final change 
of alcohol remained uncolored). The extracts were distilled together to dryness and placed in a desiccator. Since the distilled remainder was found pretty sero-reactive (active at a dilution of $1: 1600$ ), complete separation from it of the part, which involves the group lipoid and is insoluble per se, was tried by repetitions of a similar procedure. All the residues, tried and put together, (3.6 g. in total; the sero-reactive dilution, 1:6400) were washed with acetone, dried and subjected to ether fractionation, namely, they were agitated with $36 \mathrm{cc}$. of dry ether and centrifuged and the supernatant fluid was distilled in vacuo. The centrifugate $(1.7 \mathrm{~g}$. and the distilled residue here (1.0 g.) possessed nearly equal serological potencies (The dilutions where they were active were 1:12800 and 1: 6400 respectively). However, on another treatment of the latter with dry ether, after thorough drying (in a vacuum desiccator for 3 days), the part that remained undissolved ( $0.3 \mathrm{~g}$.) was found active even at a dilution of $1: 32,000$, whereas the one which had been recovered from the solution 60.7 g.) was active merely at a dilution of $1: 1600$. Followingly the both insoluble parts ( $2.0 \mathrm{~g}$. in total) were refluxed with $20 \mathrm{cc}$. benzene on a waterbath again and again (five times). Each time the mixture was centrifuged while hot. The supernatant fluids were distilled in vacuo. The amorphous brown gelatine-like substance left (Prep. I, 1.2 g.) exhibited the specific anti-iso-hemoagglutinative potency up to $5.12 \times 10^{4}$ times difution (s. Table I).

\section{TABLE I.}

Anti-iso-hemoagglutinative Potency of Prep. I from the Mucosa of Stomachs of Persons Belonging to Group A.

Both $B$ and A serum had agglutinin titre 160 and were diluted to 1:10. -: no agglutination, \pm : faint aggl., + : slight aggl., H: marked aggl., \# : strong aggl.

\begin{tabular}{|c|c|c|c|c|c|c|c|c|c|c|c|c|}
\hline \multirow[b]{2}{*}{$\begin{array}{l}\text { Group } \\
\text { of } \\
\text { erythroc. }\end{array}$} & \multicolumn{12}{|c|}{ Dilution of the substance } \\
\hline & $\bar{x} \frac{8}{x}$ & $\begin{array}{c}\times 2 \\
\times 10^{2}\end{array}$ & $\begin{array}{c}\times 4 \\
\times 10^{2}\end{array}$ & $\begin{array}{c}\times 8 \\
\times 10^{2}\end{array}$ & $\begin{array}{r}\times 1.6 \\
\times 10^{3}\end{array}$ & $\begin{array}{r}\times 3.2 \\
\times 10^{3}\end{array}$ & $\begin{array}{r}\times 6.4 \\
\times 10^{3}\end{array}$ & $\stackrel{\substack{\stackrel{0}{0} \\
x}}{x}$ & 总 & 言泀 & 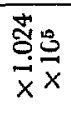 & 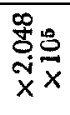 \\
\hline $\mathbf{A}$ & - & - & - & - & - & - & - & - & - & - & + & + \\
\hline B & - & + & + & + & H & H & $H$ & H & H. & H & H & HI \\
\hline
\end{tabular}

The final product had solubilities in Table II. Its analyses and optical rotation are shown in Table III.

The substance was considered a mixture when analogized from the finding on the corresponding product from pig gastric mucosa. Hence, a further fractionation by the aid of abs, alcohol was made, but no definite knowledge could be acquired as to the nature of the pure group lipoid. 


\section{TABLE II.}

Solubilities of Prep. I from the Mucosa of Stomachs of Persons Belonging to Group A.

-: insoluble, \pm : faintly sol., +: partly sol., H: mostly sol., H: completely sol.

\begin{tabular}{|c|c|c|c|c|c|c|c|c|c|}
\hline$\frac{\text { 总 }}{\frac{2}{0}}$ & $\begin{array}{c}\text { Water } \\
\text { cold hot }\end{array}$ & $\begin{array}{c}\text { Abs. } \\
\text { alcohol } \\
\text { cold hot }\end{array}$ & $\begin{array}{l}\text { Acètone } \\
\text { cold hot }\end{array}$ & $\begin{array}{l}\text { Ether } \\
\text { cold hot }\end{array}$ & $\begin{array}{c}\text { Petrol } \\
\text { ether } \\
\text { cold hot }\end{array}$ & $\begin{array}{l}\text { Benzene } \\
\text { cold hot }\end{array}$ & $\begin{array}{l}\text { Chloro- } \\
\text { form } \\
\text { cold hot }\end{array}$ & $\begin{array}{l}\text { Tetralin } \\
\text { cold hot }\end{array}$ & $\begin{array}{c}\text { Glacial } \\
\text { acetic acid } \\
\text { cold hot }\end{array}$ \\
\hline $\begin{array}{l}\text { Solub- } \\
\text { ility }\end{array}$ & \# \# & -+ & -- & -- & - & $H$ H & $H \#$ & $-H$ & - \\
\hline
\end{tabular}

TABLE III.

Composition and Optical Rotation of Prep. I from the Mucosa of Stomachs of Persons Belonging to Group A.

\begin{tabular}{c|c|c}
\hline Analysis & In per cent & $\begin{array}{c}\text { In equivalents per equivalent } \\
\text { weight }\end{array}$ \\
\hline N & 3.9 & 3.1 \\
P & 2.8 & 1.0 \\
Total carbohydrate as glucose* & 11.9 & \\
Ash $\dagger$ & 8.9 &
\end{tabular}

* Masamune and Tanabe procedure7). Since no phosphotungstic acid-precipitable substance was found in the filtrate after hydrolysis, this precipitant was not employed, neutralizing immediately the filtrate for the determination of the reducing force. T Micro analysis.

$$
\left[\alpha . \mathrm{D}^{12}=\frac{+0.023 \times 100}{1.236 \times 1}=+1.9^{\circ}\right. \text { (in chloroform) }
$$

The operation was effected as follows:-200 $\mathrm{mg}$. of the substance were treated with hot abs. alcohol again and again (five times) by refluxing each time with a $15 \mathrm{cc}$. portion of the solvent for 20 minutes. The extracts were decanted out, while hot. The brown insoluble part that had adhered to the vessel wall was semifluid while hot, and solidified on cooling -Fr. I (30 mg.). The extracts were combined and stood in an ice-chest for one day, whereupon coarse flocculent precipitates (white) appeared. These precipitates were centrifuged and dried-Fr. II (a white powder weighing $80 \mathrm{mg}$.). The supernatant fluid was evaporated to about $10 \mathrm{cc}$. and again placed in an ice-chest. The occurring deposits were also separated after one day and dried-Fr. III (a white powder, $30 \mathrm{mg}$.) - and the mother liquid was distilled in vacuo to dryness-Fr. IV (a yellow powder, $35 \mathrm{mg}$.). The anti-iso-hemoagglutinative forces and analyses of the fractions are shown in Tables IV and V.

To Divs. II and II' united $(2.3 \mathrm{~g}$.) was adapted the above series of fractionation. a) At first they were washed well with $20 \mathrm{cc}$, portions of 
TABLE IV.

Anti-iso-hemoagglutinative Potency of the Fractions of Prep. I from the Mucosa of Stomachs of Persons Belonging to Group A.

Fractions are named as in the text. The $B$ serum used had agglutinin titre 320 and was diluted to $1: 20$.

-: no agglutination, \pm : faint aggl., +: slight aggl., H: marked aggl.

\begin{tabular}{|c|c|c|c|c|c|c|c|c|c|c|}
\hline \multirow{2}{*}{ Fraction } & \multirow{2}{*}{$\begin{array}{l}\text { Group } \\
\text { of } \\
\text { erythroc. }\end{array}$} & \multicolumn{9}{|c|}{ Dilution of substances } \\
\hline & & $\begin{array}{c}\times 4 \\
\times 10^{2}\end{array}$ & $\begin{array}{c}\times 8 \\
\times 10^{2}\end{array}$ & $\begin{array}{l}\times 1.6 \\
\times 10^{3}\end{array}$ & $\begin{array}{l}\times 3.2 \\
\times 10^{3}\end{array}$ & $\begin{array}{r}\times 6.4 \\
\times 10^{3}\end{array}$ & $\begin{array}{l}\times 1.28 \\
\times 10^{4}\end{array}$ & $\mid \begin{array}{c}\times 2.56 \\
\times 10^{4}\end{array}$ & $\begin{array}{l}\times 5.12 \\
\times 10^{4}\end{array}$ & $\begin{array}{r}\times 1.024 \\
\times 10^{8}\end{array}$ \\
\hline I & A & - & - & - & - & \pm & + & $H$ & $H$ & $H$ \\
\hline II & $"$ & - & - & - & - & - & - & - & \pm & + \\
\hline III & " & - & - & - & - & - & - & - & - & \pm \\
\hline IV & $"$ & - & - & - & - & \pm & + & $H$ & $H$ & $H$ \\
\hline
\end{tabular}

TABLE $V$.

Composition of the Fractions of Prep. I from the Mucosa of Stomachs of Persons Belonging to Group A.

Fractions are named as in the text. Analyses are expressed as percentages.

\begin{tabular}{c|cccc}
\hline \multirow{2}{*}{ Fraction } & \multicolumn{5}{|c}{ Analysis } \\
\cline { 2 - 5 } & $\mathrm{N}$ & $\mathrm{P}$ & Total carbohydrate as glucose* & Ashf \\
\hline I & 5.0 & 2.5 & 16.0 & 12.5 \\
II & 3.2 & 1.3 & 14.6 & 5.6 \\
III & 3.7 & 1.9 & 13.0 & 3.7 \\
IV & 4.4 & 3.6 & 8.3 & 9.6
\end{tabular}

- Calculated from the reducing force of the hydrolysate. Analysis was made as described in the Note of Table III. † Micro analysis.

dry acetone and dried. A hygroscopic brownish powder otbained was sero-reactive at a dilution of $1: 8000$, and amounted to $0.45 \mathrm{~g}$. b) This was agitated twice with $20 \mathrm{cc}$. abs. alcohol, each time with following centrifugation. The insoluble part (a hygroscopic white powder) was $150 \mathrm{mg}$. The supernatant fluids (brownish and transparent) were distilled and the residual, washed with acetone $(20 \mathrm{cc}$.) and dried, (a brownish stuff matter) was again treated with abs. alcohol as above. $100 \mathrm{mg}$. was the insoluble part here. The substance recovered from the solution $(180 \mathrm{mg}$.) was nonactive. c) The parts undissolved (sero-reactive at a dilution of $1: 16000$ ) were again washed with acetone and completely dried, and then washed with changes (three 30 cc. portions) of ether. Almost no loss of weight occurred, but the substance (a hygroscopic, yellowish, fine powder) became twice as active as the product in b). d) It was boiled with $20 \mathrm{cc}$. benzene 
under return condenser for 20 minutes and centrifuged when cold, and the centrifugate was treated likewise once again. The extracts were distilled to dryness, $100 \mathrm{mg}$. of a gelatine-like substance with brown shade were given. This had the same potency as the material before the fractionation, notwithstanding that the benzene-insoluble part (a white powder amount. ing to about $100 \mathrm{mg}$.) was almost inactive (anti-iso-hemoagglutinative at a dilution of $1: 400$ ). The serological potency, analyses and solubilities of the final product (Prep. II) are illustrated in Tables VI, VII and.VIII.

\section{TABLE VI.}

Anti-iso-hemoagglutinative Potency of Prep. II from the Mucosa of Stomachs of Persons Belonging to Group A.

$B$ and $A$ serum had agglutinin titres of 320 and of 160 and were diluted 20 and 10 times respectively. -: no agglutination, \pm : faint aggl., +: slight aggl., H: marked aggl., H: strong aggl.

\begin{tabular}{|c|c|c|c|c|c|c|c|c|c|c|c|}
\hline \multirow{2}{*}{$\begin{array}{l}\text { Group of } \\
\text { erythrocytes }\end{array}$} & \multicolumn{11}{|c|}{ Dilution of the substance } \\
\hline & $\begin{array}{c}\times 1 \\
\times 10^{2}\end{array}$ & $\begin{array}{l}\times 2 \\
\times 10^{2}\end{array}$ & $\begin{array}{r}\times 4 \\
\times 10^{2}\end{array}$ & $\begin{array}{r}\times 8 \\
\times 10^{2}\end{array}$ & $\begin{array}{r}\times 1.6 \\
\times 10^{3}\end{array}$ & $\begin{array}{l}\times 3.2 \\
\times 10^{3} \\
\end{array}$ & $\begin{array}{r}\times 6.4 \\
\times 10^{3}\end{array}$ & $\begin{array}{r}\times 1.28 \\
\times 10^{4} \\
\end{array}$ & $\begin{array}{r}\times 2.56 \\
\times 10^{4}\end{array}$ & $\begin{array}{r}\times 5.12 \\
\times 10^{4} \\
\end{array}$ & $\begin{array}{l}\times 1.024 \\
\times 10^{5}\end{array}$ \\
\hline A & - & - & - & $=$ & - & - & $=-$ & - & -1 & \pm & $t$ \\
\hline $\mathbf{B}_{i}$ & $\dot{-}$ & + & H & $H$ & $H$ & H & $H$ & H & m & $m^{3}$ & \# \\
\hline
\end{tabular}

Composition of Prep. II from the Mucosa of Stomachs of Persons Belonging to Group A.

\begin{tabular}{c|c|c}
\hline Analysis & In per cent & $\begin{array}{c}\text { In equivalents per equivalent } \\
\text { weight }\end{array}$ \\
\hline $\mathrm{N}$ & 3.6 & 3.1 \\
$\mathrm{P}$ & 2.6 & 1.0 \\
Total carbohydrate as glucose* & 11.0 & \\
Ashf & 7.8 &
\end{tabular}

*, + Signify the same as in Tables III and V.

TABLE VIII.

Solubilities of Prep. II from the Mucosa of Stomachs of Persons Belonging to Group A.

-: insoluble, +: partly sol., H: mostly sol., H: completely sol.

\begin{tabular}{|c|c|c|c|c|c|c|c|c|c|}
\hline Solvent & $\begin{array}{l}\text { Water } \\
\text { cold hot }\end{array}$ & $\begin{array}{c}\text { Abs. } \\
\text { alcohol } \\
\text { cold hot }\end{array}$ & $\begin{array}{l}\text { Acetone } \\
\text { cold-hot }\end{array}$ & $\begin{array}{c}\text { Ether } \\
\text { cold hot }\end{array}$ & $\begin{array}{l}\text { Petrol } \\
\text { ether } \\
\text { cold hot }\end{array}$ & $\begin{array}{l}\text { Benzene } \\
\text { cold hot }\end{array}$ & $\begin{array}{l}\text { Chloro- } \\
\text { form } \\
\text { cold hot }\end{array}$ & $\begin{array}{l}\text { Tetralin } \\
\text { cold-hot }\end{array}$ & $\begin{array}{l}\text { Glacial : } \\
\text { acetic acid. } \\
\text { cold hot }\end{array}$ \\
\hline $\begin{array}{l}\text { Solub- } \\
\text { ility }\end{array}$ & H H & $-\ldots+$ & $\rightarrow-$ & -- & -7 & H \# & $H+H$ & $=H$ & $=$ \\
\hline
\end{tabular}


2). The Group Lipoid froin the Mucosa of Stomachs of Persons Belon ring to Group B.

The fresh mucosa amounted to $839 \mathrm{~g}$. (13 stomachs) altogether and the dehydrated to $156 \mathrm{~g}$. The hot-alcoholic extracts were $1200 \mathrm{cc}$. in total.

The precipitates (Div. II, $100 \mathrm{mg}$.) from the tissue extracts when cold were washed with acetone. The 5 ibstance after the washing $(70 \mathrm{mg}$.; mostly soluble in water) exhibited anti-iso-agglutinative force towards B erythrocytes at a dilution of $1: 6400$. However, because of small quantity of the material, the group lipoid in it was not traced.

The remainder after distillation of the mother liquid of Div. IIDiv. I-was treated with acetone as in 1), and $1.2 \mathrm{~g}$. of a coarse brownish powder (hygroscopic) were given. Turther fractionation was carried out also similar to above, and $0.65 \mathrm{~g}$. o: $^{\prime}$ the cold-alcohol-insoluble substance (a yellowish powder), $0.42 \mathrm{~g}$. of the ether-insoluble (a fine white powder) and $0.12 \mathrm{~g}$. of the hot-benzene-solubl : (a fine white powder) were obtained in turn. The final product inhibited the iso-agglutination of $B$ erythrocytes at a dilution of $1: 2.56 \times 10^{4}$ and that of $A$ erythrocytes at a dilution of 1 : $4 \times 10^{2}$, and had the same solubilities as Prep. I of the Goup A lipoid above. Analayses: N 3.6\%; P 2.6\%; total carbohydrate as glucose $9.4 \%$; ash $8.3 \% .[a]_{\mathrm{D}}^{12}=\frac{+0.021 \times 100}{1.023 \times 1}=+2.1^{\circ}$ (in chloroform).

3) The Group Lipoid from the Mucosa of Stomachs of Persons Belonging $t$, Group O.

In this case, the deposits from he hot-alcoholic tissue extracts when cold and the substance that remained in solution were fractioned without serological assay of the intermediat; products. The final product from the former division exhibited remar sable reaction with an anti-O serum treated with Be erythrocytes, while that of the latter was entirely devoid of the activity.

The fresh mucosa, $927 \mathrm{~g}$. (numk er of stomachs, 14). The tissue after dehydration, $174 \mathrm{~g}$. The hot-alcohe lic extracts altogether, $1260 \mathrm{cc}$. The deposits in the cold were separated and dried and $0.7 \mathrm{~g}$. of a yellowish brittle clump was given-Div. II. From the distilled residue (a syrup) of the mother liquid-Div. I, $1 \mathrm{~g}$. of the acetone-insoluble substance (a coarse brownish hygroscopic powder), $0.6 \mathrm{~g}$. of the cold-abs. alcohol-insoluble, $0.45 \mathrm{~g}$. of the dry-ether-insoluble and $0.35 \mathrm{~g}$. of the hot-henzenesoluble (a light, brown powder) wire obtained in turn. Yields of the products by successive subdivision $0^{*}$ Div. II were: the acetone-insoluble (a coarse hygroscopic powder with brown shade), $0.5 \mathrm{~g}$; the cold-abs. alcohol-insoluble, $0.4 \mathrm{~g}$; the dry-ether-insoluble (a fine, very hygroscopic, 
white powder), $0.35 \mathrm{~g} . ;$ the hot-benzene-soluble (a brown gelatinous substance), $0.25 \mathrm{~g}$.

The both final products showed solubilities similar not only mutually but also to the corresponding preparations of the Group A and B lipoids. Each of them was Group A-active at a dilution of 1:400 and Group. B, active at a dilution of $1: 200$, but the substance produced from Div. II alone reacted with an anti-O serum [Increasig volumes $(8,10,12,14,16$ and 18, cc.) of $10 \%$ suspensions of $\mathrm{O}$ erythrocytes in physiological saline were injected at intervals of two days into V. jugularis communis of a goat, and after 1 week from the last injection, the blood was shed] adsorbed with Be erythrocytes at a dilution of $1: 1.28 \times 10^{4}$ (s. Tables IX and X).

TABLE IX.

Agglutination of $\mathrm{O}$ and Be Erythrocytes by an Anti-O Serum Treated with Be Erythrocytes.

Adsorption: To $3 \mathrm{cc}$. of the immune serum diluted 10 times was added $1 \mathrm{cc}$. of Be erythrocytes and after standing at room temp. $\left(8^{\circ} \mathrm{C}\right)$ for 30 minutes, centrifuged. -: no agglutination, \pm : faint aggl., + : slight aggl.

\begin{tabular}{c|c|c|c|c|c}
\hline \multirow{3}{*}{ Group of erythrocytes } & \multicolumn{5}{|c|}{ Dilution of the immune serum } \\
\cline { 2 - 6 } & $\times 10$ & $\times 20$ & $\times 40$ & $\times 80$ & $\times 160$ \\
\hline $\mathrm{O}$ & + & + & + & \pm & - \\
$\mathrm{Be}$ & \pm & - & - & - & - \\
\hline
\end{tabular}

TABLE X.

Agglutination of $\mathrm{O}$ Erythrocytes by an Adsorbed Anti-serum, which had been Treated in Advance with the Final Products from the

Mucosa of Stomachs of Persons Belonging to Group O.

The serum diluted 10 times and treated with Be erythrocytes in Table

IX was employed for the present assay.

-: no agglutination, \pm : faint aggl., + : slight aggl.

\begin{tabular}{|c|c|c|c|c|c|c|c|c|c|}
\hline \multirow{2}{*}{$\begin{array}{c}\text { Division wherefrom } \\
\text { the substance was } \\
\text { obtained }\end{array}$} & \multicolumn{9}{|c|}{ Dilution of substances } \\
\hline & $\begin{array}{r}\times 1 \\
\times 10^{2}\end{array}$ & $\begin{array}{c}\times 2 \\
\times 10^{2}\end{array}$ & $\begin{array}{r}\times 4 \\
\times 1 c^{2}\end{array}$ & $\begin{array}{r}\times 8 \\
\times 10^{2}\end{array}$ & $\begin{array}{r}\times 1.6 \\
\times 10^{3} \\
\end{array}$ & $\begin{array}{r}\times 3,2 \\
\times 10^{3}\end{array}$ & $\begin{array}{r}\times 6.4 \\
\times 10^{3}\end{array}$ & $\begin{array}{r}\times 1.28 \\
\times 10^{4}\end{array}$ & $\begin{array}{l}\times 2.56 \\
\times 10^{4}\end{array}$ \\
\hline I & \pm & + & \pm & + & + & + & + & + & + \\
\hline & & & & & - & - & - & - & + \\
\hline
\end{tabular}

The Group O-active product analyzed: N 3.6\%; P 2.7\%; total carbohydrate as glucose $9.4 \%$; ash $11.3 \%$. It had the rotation: $[\alpha]_{\mathrm{p}}=\frac{+0.015 \times 100}{1.011 \times 1}=+1.5^{\circ}$ (in chloroform). Its solubilities resembled 
those of the corresponding product of the Group A lipoid.

4) The Group Lipoid from Gastric Cancers of Persons Belonging to Group A.

Cancer material: $632 \mathrm{~g}$. (30 cancers) in a fresh state and $98.5 \mathrm{~g}$. when dehydrated.

The deposits, that had come out from the hot-alcoholic tissue extracts when cold, were no more than $50 \mathrm{mg}$. and, in addition, their part insoluble in acetone $(30 \mathrm{mg}$.) inhibited the iso-agglutination of A erythrocytes only at a dilution of $1: 100$. The transparent yellowish mother fluid was distilled in vacuo and the remainder treated with acetone as above. The insoluble part here amounted to $0.5 \mathrm{~g}$. The cold-alcohol-insoluble substance separated therefrom was $0.36 \mathrm{~g}$. and on fractioning with ether of its balance after serological assay $(0.35 \mathrm{~g}$.) remained $0.3 \mathrm{~g}$. of a fine white powder undissolved. Of this $0.25 \mathrm{~g}$. dissolved in hot benzene. The preparation finally obtained was a brownish brittle clump and exhibited the specific inhibitory power to iso-agglutination of A erythrocytes at a dilution of $1: 6400$. It had solubilities same as the corresponding preparations from normal gastric mucosa. N $3.6 \%, \mathrm{P} 2.6 \%$, total carbohydrate as glucose $10.9 \%$, ash $12.4 \% . \quad[\alpha]_{D}^{22}=\frac{+0.040 \times 100}{1.028 \times 1}=+3.9^{\circ}$ (in chloroform).

\section{Summary.}

1) It was tried to separate the blood group lipoids by the aid of organic solvents from human gastric mucosa and gastric cancers.

2) All of the preparations of the A, B and O group-lipoids had similar composition with respect to $\mathrm{N}-, \mathrm{P}$ - and carbohydrate-content and similar solubilities.

3) They rotated $\mathrm{D}$ light to the right but slightly.

4) Group A lipoid from gastric cancer was serologically much less active than the corresponding lipoid from the normal mucosa.

5) An assumption was expressed that the liver metastasis of gastric cancer contains a group lipoid same as the one in its original growth.

We thank to the Education Department for a grant given through the Grant Committee of the Science Council to support this investigation and to Prof. T. Murakami for the gift of the anti-O immune serum.

H. M.

\section{References.}

1) Masamune and Siozima, Tohoku J. Exp. Med., this volume, p. 319.

2) Aikawa, ibid., 1949, 51, 367.

3) Matuda, ibid., 1951, 53, 333.

4) Hamasato, ibid., 1950, 52, 17. 
5) Oh-Uti, Tohoku J. Exp. Med., 1949, 51, 297.

6) Matuda, ibid., 1951, 54, 1.

7) Masamune and Tanabe, J. Bioch., 1938, 28, 21. Cf, also Masamune, ibid., 1933, 18, 259. 